\title{
Mechanical Properties of Boronized AISI 316, AISI 1040, AISI 1045 and AISI 4140 Steels
}

\author{
A. $\mathrm{CALIK}^{a}, \mathrm{O} \cdot \mathrm{SAHIN}^{b}$ AND N. UCAR \\ ${ }^{a}$ Department of Mechanical Education, Technical Education Faculty \\ Suleyman Demirel University, Isparta, Turkey \\ ${ }^{b}$ Physics Department, Art and Science Faculty, Mustafa Kemal University \\ Hatay, Turkey \\ ${ }^{c}$ Physics Department, Art and Science Faculty, Suleyman Demirel University \\ Isparta, Turkey
}

(Received June 18, 2008; revised version December 26, 2008)

\begin{abstract}
In this study, some mechanical properties of borided and unborided four steels were investigated. Boronizing of steels was performed by powder pack method at $1210 \mathrm{~K}$ for $4 \mathrm{~h}$. The hardness of borides, boride layer thickness and room temperature tensile properties were measured and it was observed that hardness and tensile properties strongly depend on chemical composition of steels. In addition, the effect of a notch on impact behavior was examined by conducting the Charpy tests on borided and unborided steels. The greatest notch toughness was found for a steel AISI 316 with a microstructure consisting of different $\mathrm{C}, \mathrm{Ni}$ and $\mathrm{Cr}$ chemical composition compared to AISI 1040, 1045 and 4140 steels.
\end{abstract}

PACS numbers: 62.20.-x, 62.20.Qp, 68.35.Fx

\section{Introduction}

Austenitic stainless steels are extensively used in nuclear reactors, biomedical implants, as well as in component for chemical and food industries $[1,2]$. In considering the engineering materials, the main problem with austenitic stainless steels is that it has poor wear-resistance yield strength, fracture and impact toughness $[3,4]$. In recent years, extensive studies on the improvement of mechanical properties of these materials have been carried out. Corresponding to this, it has been shown that using surface treatment on engineering materials increases the wear strength, decrease the friction coefficient, and improve corrosion resistance $[5,6]$. Therefore, the use of surface coatings opens up the possibility for material designs in which the specific properties are located where they are most needed. Industrial boriding can be applied to most ferrous steels such as structural steels (AISI 1014, 1045, and 4140) as well as to austenitic stainless steels [7]. Thus, boronizing has long been used to improve the surface properties of valves, burner nozzle, etc. in the utility industry as boride layers have a high hardness, oxidation resistance, strong indicator of wear resistance and fracture strength $[8,9]$.

Engineered systems is often set by intended or unintended stress concentrators, including cracks, notches, bends or holes due to manufacturing process, service ap- plications or damaged developed during service. These stress concentrators require that local stresses not exceed certain stress limits which are typically well below those that would be acceptable in uniform dimension components. Currently, much attention has been paid to notch and cracks effect especially in reactor structural components due to the ductility loss caused by irradiating environments [10-12]. It has been shown that notch in structural components give rise to localized stress concentration which decreases the maximum load the component can sustain and may generate a crack or lead to early crack initiation [13]. Hence, a criterion to evaluate the maximum load that a component with a notch can sustain is of paramount importance. On the other hand, experimental and numerical studies were performed to ascertain the influence of $\mathrm{V}$-notches on the strength of different brittle materials [13]. It has been noticed that notch depth plays an important role in notch strengthening and mechanical properties degradation and upper self-energy obtained from the Charpy impact tests of steels change due to amount granular bainite having a large effective grain size [14].

It is well known that yield strength and impact toughness are very much interlinked, with toughness usually being more important than strength. In the present work, the thermochemical surface treatments and also 
tensile properties of four steels were discussed. In addition, the influence of $\mathrm{V}$-notch on the impact properties of four different borided and unborided steels were obtained.

\section{Experimental method}

AISI 1040, 1045, 4140 and 316 steels were used in this study. Chemical compositions of the four steels were listed in Table I. Test samples were cut from a $55 \times 10 \times 10 \mathrm{~mm}^{3}$ steel plate. The boriding of the steels was achieved in a solid medium using the powder pack method. In this method, commercial EkaborII boron source and activator (ferro-silicon) were thoroughly mixed to form the boriding packet. The test samples and packet were heated in electrical resistance furnace for $4 \mathrm{~h}$ at $1210 \mathrm{~K}$ under atmospheric pressure. After this process, borided samples were removed from the furnace and cooled in air. Borided samples were sectioned from one side and prepared metallographically up to 1200 -grid emery paper and then polished using $0.3 \mu \mathrm{m}$ alumina pastes. Polished samples were etched by $4 \% \mathrm{Ni}-$ tal before tests.

\section{TABLE I}

The chemical composition of test materials.

\begin{tabular}{c|c|c|c|c|c|c|c|c|c}
\hline \hline \multirow{2}{*}{$\begin{array}{c}\text { Steel } \\
\text { type }\end{array}$} & \multicolumn{8}{|c}{ Element in wt. \%, Fe $=$ bal. } \\
\cline { 2 - 10 } & $\mathrm{C}$ & $\mathrm{Si}$ & $\mathrm{Mn}$ & $\mathrm{Cr}$ & $\mathrm{Ni}$ & $\mathrm{Mo}$ & $\mathrm{P}$ & $\mathrm{S}$ & $\mathrm{Nb}$ \\
\hline 316 & 0.04 & 0.43 & 1.37 & 17.21 & 10.43 & 1.63 & 0.04 & 0.01 & 0.02 \\
1040 & 0.35 & 0.20 & 0.80 & - & - & - & 0.04 & 0.05 & - \\
4140 & 0.39 & 0.27 & 0.78 & 0.90 & 0.03 & 0.18 & 0.01 & 0.01 & - \\
1045 & 0.47 & 0.29 & 0.71 & 0.18 & 0.03 & - & 0.02 & 0.04 & -
\end{tabular}

TABLE II

Tensile and impact properties of investigated steels (the values in the parenthesis belong to boronized steels).

\begin{tabular}{c|c|c|c|c}
\hline \hline Steel type & \multicolumn{2}{|c|}{$\begin{array}{c}\text { Tensile } \\
\text { stress[MPa] }\end{array}$} & $\begin{array}{c}\text { Yield stress } \\
{[\%]}\end{array}$ & $\begin{array}{c}\text { Elongation } \\
\text { [\%arpy impact } \\
\text { energy [J] }\end{array}$ \\
\hline AISI 316 & $570(520)$ & $390(400)$ & $51(28)$ & $155(140)$ \\
AISI 1040 & $700(610)$ & $420(440)$ & $17(15)$ & $27(19)$ \\
AISI 4140 & $735(610)$ & $460(500)$ & $19(22)$ & $23(10)$ \\
AISI 1045 & $770(740)$ & $510(620)$ & $17(13)$ & $23(18)$
\end{tabular}

Borided and unborided steels were pulled with an Instron type machine at $10^{-6} \mathrm{~s}^{-1}$ strain rate in the room temperature. Load and elongation curves were recorded during the tensile tests and were converted into engineering stress-strain curves. Tensile stress, yield stress and elongation were determined on these curves and were given in Table II. To determine the hardness of the borided steels a Vickers microhardness tester with a load of $100 \mathrm{~g}$ was used. Many indentations were made on each coating film under each experimental condition to check reproducibility of hardness data. In addition, the Charpy impact tests were performed using an instrumented Charpy impact testing machine with an energy capacity of $300 \mathrm{~J}$ and tests were conducted using the $10 \times 10 \times 55 \mathrm{~mm}^{3}$ size of standard V-notched Charpy specimen at the room temperature. Notch of $2 \mathrm{~mm}$ depth were worked by milling with a $45^{\circ}$ double angle cutter. Further experimental details were described in Ref. [15].

\section{Results and discussion}

Boronizing being a thermochemical diffusion process has been applied to a wide range of materials including ferrous and non-ferrous materials [16-18]. It is well known that a boride layer on the upper surface of the specimen forms as a result of boron diffusion into the surface in the boronizing process. As seen in Fig. 1a and b, optical examinations revealed that borides formed on the surface of steels have columnar (AISI 316) and dentricular morphology (AISI 1045, 1045 and 4140) due chemical composition. Moreover, three distinct regions were identified on the surface of steels: (i) borides, (ii) transition zone and (iii) matrix. In general, boriding carbon steels usually lead to formation of two borides $[7,19]$. In the present study, the boride layer of AISI 1040, 1045 and 4140 have $\mathrm{FeB}$ and near the surface and $\mathrm{Fe}_{2} \mathrm{~B}$ in vicinity of the steel matrix whereas the AISI 316 has $\mathrm{Ni}_{3} \mathrm{~B}$ and $\mathrm{CrB}$ in addition to $\mathrm{Fe}_{2} \mathrm{~B}, \mathrm{FeB}$ phases (Fig. 2a and b). Previous studies have been shown that the characteristics of this boride layer depend on the physical state of the boride source used, boronizing temperature, treatment time, chemical composition, diffusion time, stress and properties of the boronized materials [7, 20, 21]. In the present investigation, the thickness of the boride layer of borided samples were found to be in the range of 50$115 \mu \mathrm{m}$. Also, it can be seen from Fig. 3 that the boride layer thickness formed on the steels decreases with increasing carbon (C) content. The same results for SAE 1010, SAE 1040, D2 and 304 steels have been also indicated in Ref. [22].

The distribution of the Vickers hardness values of the boride layers in the borided steels was shown in Fig. 3 . In this figure, it is possible to observe how the hardness of borided steels samples changes from the boride layer to matrix. It is also seen from Fig. 3 that the hardness of both the boride layers is much higher than that of matrix because of the presence of hard $\mathrm{FeB}$ and $\mathrm{Fe}_{2} \mathrm{~B}$ phases in boride layer as determined by X-ray diffraction (XRD) (Fig. 2a and b). Meanwhile, especially at boride layer and transition zone region, hardness values increase with increasing $\mathrm{C}$ content (Fig. 3). This situation can be explained with the behavior of $\mathrm{C}$ atoms. It is well known that the $\mathrm{C}$ atoms do not dissolve significantly in the boride layer and also the $\mathrm{C}$ atoms are driven from the boride layer to the matrix during boronizing treatment $[7,23]$. On the other hand, we think that there is an important role on boride layer of $\mathrm{Cr}$ and $\mathrm{Ni}$ elements. Clearly, when the $\mathrm{Cr}$ and $\mathrm{Ni}$ content of steels were increased, the boride layer were thinner and soft. Thus, 


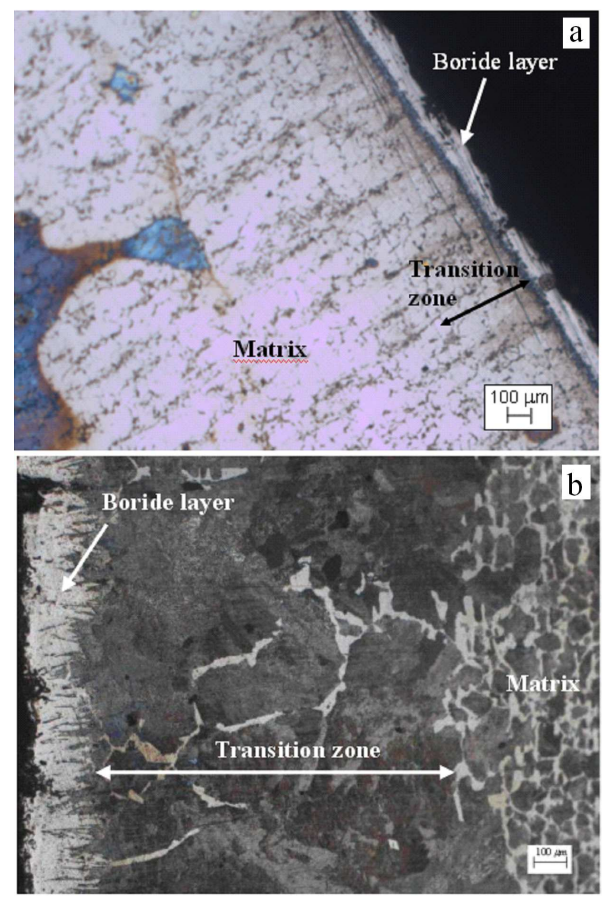

Fig. 1. Optical microscopy cross-sectional view of boronized steels at $1210 \mathrm{~K}$ for $4 \mathrm{~h}$ : (a) AISI 316 and (b) AISI 1040.

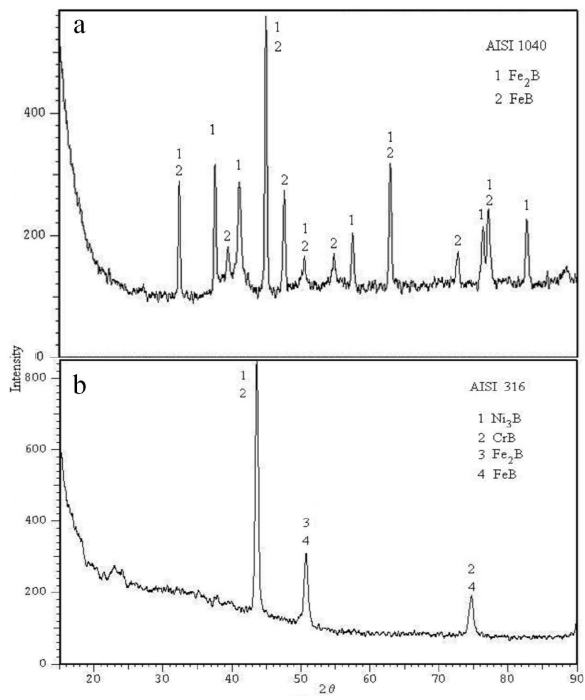

Fig. 2. X-ray diffraction patterns of boronized steels at $1210 \mathrm{~K}$ for $4 \mathrm{~h}$ : (a) AISI 1040 and (b) AISI 316.

the difference in the hardness of boride layers of steels may be explained as the effect of alloying elements of the substrates.

Room temperature tensile properties for steels were shown in Fig. 4 and listed in Table II. It is evident from these table and Fig. 4 that the tensile stress and yield stress decrease with decreasing $\mathrm{C}$ content for unborided steels as well as for borided steels. In contrast, the elon-

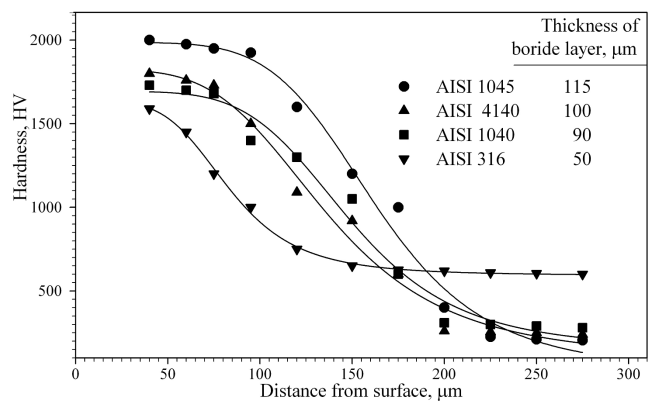

Fig. 3. The hardness variation of boronized steels as a function of distance.

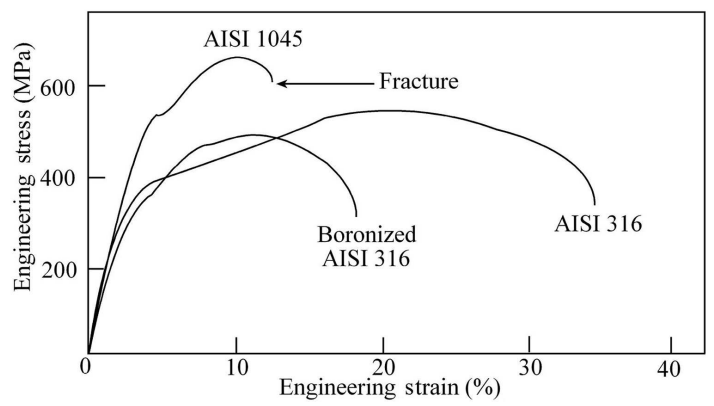

Fig. 4. Engineering stress-strain curves obtained from the room temperature tensile test of the AISI 316 and AISI 1045 steels with notch.

gation increases with decreasing $\mathrm{C}$ content. This could lead to brittle fracture even though the materials, in unborided condition, normally experiences ductile fracture. One can understand that the mechanical properties change with the boronizing due to surface modification as expected in considering the plastic deformation of materials.

Nowadays, structural materials require various properties such as high strength, excellent corrosion and wear resistant due to the demands for high performance and severe service environments of machine components [24]. In order to meet these demands, many studies have been performed on especially steel samples. However, little attention has been paid to the tensile behavior of notched parts which have been given a surface treatment. In literature [25] it has been pointed out that the yield stress of notched specimens of ductile materials is usually higher than that of unnotched specimens owing to constraint of plastic flow. In notch brittle materials, fracture occurs at lower nominal stresses. Therefore, depending on whether the nominal ultimate tensile stress in the notched specimen is higher or lower than in unnotched specimens, materials are classifed as being notch ductile or notch brittle, respectively. V-notches are one of the simplest and most frequent geometries that appear in testing samples and in notched structural components, and the search for criterion of $\mathrm{V}$-notched components has stimulated researchers for many years [13]. In considering the plastic deforma- 
tion of materials having notch and cracks, the Charpy impact test, also known as the Charpy V-notch test, is a standardized high strain-rate test which determines the amount of energy absorbed by a material during fracture. This absorbed energy (the Charpy impact energy) is related to the area under the total stress-strain curve and is a measure of a given material's toughness and acts as a tool to study temperature-dependent brittle-ductile transition [26]. One can expect that materials with large values of strength and ductility to have large Charpy impact energy. At the present study, the impact properties for specimens with and without notches were also studied. After notching, the impact energy were greatly decreased, whereas this energy is above $300 \mathrm{~J}$ for all steels. The impact energy shows the lowest decrease for AISI 316 steel whereas the decrease is higher for the other steels (Fig. 4 and Table II). In general, the introduction of notches reduces the Charpy impact energy due to the fact that the notch structure confines the plastic deformation to the vicinity of the notch tip [27]. It is seen from Table II and Fig. 5a that the AISI 316 have ductile properties and high impact energy within an austenictic phase. This behavior of AISI 316 can be explained by the thermal process. It is well known that the thermal process does not affect the AISI 316 as much as the other steels. Therefore, AISI 316 does not have a phase transformation and it has also a small boronizing affinity. This result also can be confirmed by a thin thickness of the borided layer (Fig. 3). On the other hand, we say that the hardness and brittle fracture increase as the impact energy decreases due to introduced grain growth at the transition zone of boronized AISI 1040 steel (Fig. 5b), AISI 4140 and AISI 1045 steels.

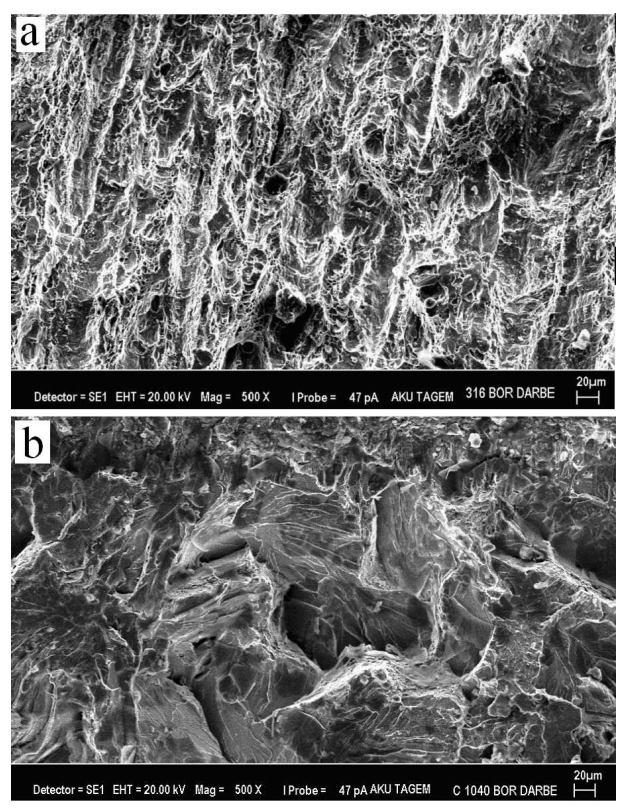

Fig. 5. Scanning electron micrographs (SEM) of the Charpy impact specimens for the (a) boronized AISI 316, (b) boronized AISI 1040 steels.

\section{Conclusions}

Main conclusions obtained by present study are as follows:

1. Boride layers formed on the steels have a columnar and dentricular morphology. The microstructure of the borided steels surfaces showed three distinct regions such as boride layer, transition zone and matrix.

2. The microhardness is characterized by a gradient decreasing from the surface to interior, which is associated with a change in boron content from all steels.

3. The chemical composition of steels has a very important role on the hardness, tensile properties, impact energy and the thickness of boride layer.

\section{References}

[1] M.C.M. Farias, R.M. Souza, A. Sinatora, D.K. Tanaka, Wear 263, 111 (2007).

[2] U. Sen, S. Sen, Mater. Character. 50, 261 (2003).

[3] P.A. Dearnley, G. Aldrich-Schmith, Wear 256, 491 (2004).

[4] L. Shi, D.O. Northwood, Acta Mater. 43, 453 (1995).

[5] E. Atik, Mater. Struct. 31, 418 (1998).

[6] A. Erdemir, C. Bindal, Surf. Coat. Technol. 76-77, 443 (1995).

[7] I. Ozbek, C. Bindal, Surf. Coat. Technol. 154, 14 (2002).

[8] B.S. Mann, Wear 208, 125 (1997).

[9] R.X. Yan, X.M. Zhang, J.W. Xu, Z.G. Wu, Q.M. Song, Mater. Chem. Phys. 71, 107 (2001).

[10] A.P. Antoniou, R. Onck, A.F. Bastawros, Acta Mater. 52, 2377 (2004).

[11] E.W. Andrews, Mater. Lett. 57, 532 (2002).

[12] W.Y. Lu, M.F. Horstemeyer, J.S. Korellis, R.B. Grishabar, D. Mosher, Theor. Appl. Fract. Mech. 30, 139 (1998).

[13] F.J. Gomez, M. Elices, Eng. Fract. Mech. 70, 1913 (2003).

[14] S.Y. Shin, B. Hwang, S. Lee, N.J. Kim, S.S. Ahn, Mater. Sci. Eng. A 458, 281 (2007).

[15] K. Delikanlı, A.H. Calik, A. Uzun, Fen Bilimleri Enstitüsü Dergisi 5, 99 (2003) (in Turkish).

[16] M. Usta, Surf. Coat. Technol. 194, 251 (2005).

[17] T.S. Eyre, Wear 34, 383 (1975).

[18] K.G. Anthymidis, G. Stergioudis, D.N. Tsipas, Sci. Technol. Adv. Mater. 3, 303 (2002).

[19] C.M. Brakman, A.W.J. Gommers, E.J. Mittemeijer, Mater. Res. 4, 1354 (1989).

[20] H. Kemi, C. Sasaki, M. Kitamura, N. Satomi, Y. Ueda, M. Nishikawa, J. Nucl. Mater. 26, 1108 (1999). 
[21] L.L. Oian, G.A. Stone, J. Mater. Eng. Performance 4, 59 (1995).

[22] E. Atik, U. Yunker, C. Meric, Tribol. Int. 36, 155 (2003).

[23] A.K. Sinha, Boronizing, ASM Int., Materials Park (Oh) 1991, Vol. 4, Sect. 2, p. 437.

[24] I. Jauhari, S. Rozali, N. Masdek, O. Hiroyuki, Mater. Sci. Eng. A 466, 230 (2007).
[25] F. Bohner, J.K. Gregory, U. Weber, S. Schmauder, Mech. Mater. 31, 627 (1999).

[26] Y.J. Chao, J.D. Ward Jr., R.G. Sands, Mater. Design 28, 551 (2007).

[27] X. Wu, X. Pan, J.F. Stubbins, J. Nucl. Mater. 361, 228 (2007). 